\title{
The Stability of Beta Coefficient in China's Stock Market
}

\author{
Yipeng Ye \\ Faculty of Finance, College of Economic, Jinan University, Guangzhou, China \\ Email: yipengye@163.com
}

How to cite this paper: Ye, Y.P. (2017) The Stability of Beta Coefficient in China's Stock Market. Journal of Service Science and Management, 10, 177-187. https://doi.org/10.4236/jssm.2017.102016

Received: February 21, 2017

Accepted: April 17, 2017

Published: April 20, 2017

Copyright (C) 2017 by author and Scientific Research Publishing Inc. This work is licensed under the Creative Commons Attribution International License (CC BY 4.0).

http://creativecommons.org/licenses/by/4.0/

\begin{abstract}
CAPM (Capital asset pricing model) is widely used in asset pricing, project evaluating and investment deciding. Beta coefficient, one of the core tasks of CAPM, its accuracy and stability are of great significance. Weekly China's stock return data have been used. Firstly, analyzed the differences of mean value, maximum value and minimum value of beta coefficients which regressed by different length of time. Secondly, introduced T statistic to test the mean difference of beta which regressed by different length of time. Thirdly, used dummy variables to test the stability of beta coefficients and found that the optimal length of time for beta estimating was 12 months. In addition, several investigations about the relationship between the stability of bate coefficients and markets, industries, market size have been done finally.
\end{abstract}

\section{Keywords}

Mean Difference of Beta Coefficient, T Statistic, Virtual Variable, Stability of Bate Coefficient

\section{Introduction}

CAPM (Capital asset pricing model) was initially proposed by Sharpe (1964) [1]. The formula of CAPM is following:

$$
r_{i}=r_{f}+\beta_{i}\left(r_{m}-r_{f}\right)
$$

where, $r_{i}$ is weekly return of stock $i(i=1,2,3 \cdots 208) . r_{f}$ is the risk free rate. $r_{m}$ is weekly return of market portfolio. $\beta_{i}$ is the beta coefficient of stock $i(i=1,2,3 \cdots 208)$.

Beta coefficient, the slope of CAPM, measures the return sensitive between a single stock and the market index which is regarded as a measurement of systematic risk. Beta is 1 for market portfolio.

In researching about the stability of beta coefficients, Fabozzi, F.J. and Francis, 
J.C. (1978) used 700 samples in the NYSE (New York Stock Exchange) and drew a conclusion that the beta is unstable [2]. In researching the relationship between the estimate duration and the beta stability, Marshall E. Blume (1971) did the researches and proved the beta was more stable with the increases of the estimation duration and more stable in bigger [3]. Rodeny, Gar and Griepentrog (1978) used the sampled in Standard and Poor and found that the optimal duration for beta estimation are 4 years [4]. Robert D. Brooks, Robert W. Faff and Mohamed Ariff (1998) used the data from Singapore Exchange and the time phase was from 1986 to 1993 and drew a conclusion that the beta is unstable in Singapore's stock market [5].

For the beta stability between single stock and portfolio, Levitz (1974) found that the beta is stable in portfolio and highly unstable in individual [6].

The researches above are mainly in a quote-driven market and developed market. For order-driven market, Keith S. K. Lam (1999) took investigations on Hong Kong market for the period 1980-1993 and found that the beta is stable in short and median term but unstable in long term [7].

For developing countries, Soumya Guha Deb and Sagarika Misra (2011) used dummy variable model test the beta stability in Indian stock market, time phase was from 1996 to 2010, proved that the beta was unstable in the short-term [8].

The paper explores the beta stability in China's stock market, aims to find the relationship between the beta stability and the estimate duration, enhances the beta stability studies in China.

\section{Data and Methodology}

\subsection{Sources of Data}

The numbers of Sample were 208 and were selected in the Shanghai Stock Exchange and the Shenzhen Stock Exchange which were listed before 2008. The method for sample selection was stratified sampling method according to the market size and industries. Firstly, the proportion of sample is determined by the population in different industry. For example, if the proportion in the manufacturing industry according to the population is $30 \%$, then the sample numbers in it are 62 (calculated by $208 \times 30 \%$ ). Secondly, as the sample numbers in each in different industry has been determined. Population in each industry is ranged from smallest size to biggest size. After that, divided the population into several cells and take the samples from different cells in order to make the samples differentiate in market value.

The Shanghai Composite Index has been selected as a proxy of market portfolio. Time periods for this study last from January 2008 to December 2013. Weekly China's stock return data have been used and the formula for return calculating is following:

$$
r_{i}=\ln \left(p_{t}\right)-\ln \left(p_{t}-1\right)
$$

where, $r_{i}$ is the weekly return of stock $i . p_{t}$ is the close price for stock $\mathrm{i}$ for week t. $p_{t}-1$ is the close price for stock $i$ for week $t-1$. 


\subsection{Using t Statistic to Test Beta Difference}

Based on the weekly yield data of the listed companies, the estimated length of 6 months, 12 months, 18 months, 24 months, 36 months, 48 months, 60 months and 72 months using OLS beta Value, the calculation model for the capital asset pricing model, as follows:

$$
r_{i}=r_{f}+\beta_{i}\left(r_{m}-r_{f}\right)+\varepsilon_{i}
$$

where, $r_{i}$ is weekly return of stock $i(i=1,2,3 \cdots 208) . \quad r_{f}$ is the risk free rate. $r_{m}$ is weekly return of market portfolio. $\beta_{i}$ is the beta coefficient of stock $i(i=1,2,3 \cdots 208) . \quad \varepsilon_{i}$ is the residual item.

Calculate and compare the difference between the mean value, the maximum value and the minimum value of the beta at different length of time and using $T$ statistic model to test the mean difference [8].

$$
\begin{gathered}
t=\frac{\bar{x}_{i}-\bar{x}_{j}}{s_{x_{i} x_{j}} \sqrt{\frac{z}{n}}} \\
s_{x_{i} x_{j}}=\sqrt{\frac{s_{x_{i}}^{2}+s_{x_{j}}^{2}}{2}}
\end{gathered}
$$

where, $\bar{x}_{i}$ is the mean value of beta in different length of time for time $i . \bar{x}_{j}$ is the mean value of beta in different length of time for time $j . s_{x_{i} x_{j}}$ is a standard deviation. $s_{x_{i}}^{2}$ is the variance of the beta for time $i$ and $s_{x_{j}}^{2}$ is the variance of the beta for time $j(i \neq j)$. Degrees of freedom for $T$ statistic are $2 n-2$. The null hypothesis is there is no difference in beta between time $I$ and time $j$ and the significant level are $5 \%$ and $10 \%$.

\subsection{Using Dummy Variable to Test the Beta Stability}

The model used to test the stability of beta coefficient including several dummy variables. [8]

$$
r_{i}=r_{f}+\beta_{i}\left(r_{m}-r_{f}\right)+\sum_{j=1}^{k} b_{j i} r_{m} D_{j}+\varepsilon_{i}
$$

where, $r_{i}$ is weekly return of stock $i(i=1,2,3 \cdots 208) . \quad r_{f}$ is the risk free rate. $r_{m}$ is weekly return of market portfolio. $\beta_{i}$ is the beta coefficient of stock $i(i=1,2,3 \cdots 208) . k(k=1,2,3,5,11)$ is the numbers of dummy variables. When the length of time for estimation is 6 months, $k$ is 11 . When the length of time for estimation is 12 months, $k$ is 5 . When the length of time for estimation is 18 months, $k$ is 3 . When the length of time for estimation is 24 months, $k$ is 2 . When the length of time for estimation is 36 months, $k$ is $1 . D_{j}$ is dummy variable $j . \quad b_{j i}$ is the coefficient of dummy variable $j$ and stock $i . \quad \varepsilon_{i}$ is the residual item.

The significant level is $5 \%$ and $10 \%$. If the dummy variable is significant means beta is unstable, conversely, if the dummy variable is un-significant means the beta is stable. Otherwise, beta is supposed to increase in the corresponding time phase if the dummy variable is significant and positive, it is sup- 
posed to decrease if the dummy variable is significant and negative.

All the regression mentioned above were made by Excel and Eviews.

\subsection{Additional Investigations}

Additional investigations include testing the difference of beta stability in difference industries, difference markets and the relationship between the beta stability and the market size.

\section{Results and Analysis}

\subsection{Sample Selection}

The numbers of sample are 208 and the industry distribution has been showed in Table 1. Companies listed before 2008 mainly concentrated in manufacturing industry and the proportion is $56.59 \%$. In order to make more researches in different industries this paper lower its proportion to $26.92 \%$. The five highest proportion industries including manufacturing, real estate, wholesale and retail, utilities, transportation. As showed in Table 1.

\subsection{Beta Difference in Difference Length of Time}

1) Beta characters in different length of time

As showed in Table 2, all the beta coefficients are range from 0.5 to 2.0, the

Table 1. Industries distribution of samples.

\begin{tabular}{cccc}
\hline Industry & Market proportion & NO. of samples & Sample proportion \\
\hline Manufacturing & $56.69 \%$ & 56 & $26.92 \%$ \\
Real estate & $8.98 \%$ & 50 & $24.04 \%$ \\
Wholesale and retail & $8.38 \%$ & 30 & $14.42 \%$ \\
Utilities & $4.86 \%$ & 25 & $12.02 \%$ \\
Transportation & $4.19 \%$ & 19 & $9.13 \%$ \\
Others & $16.90 \%$ & 28 & $13.47 \%$ \\
Total & $100 \%$ & 208 & $100 \%$ \\
\hline
\end{tabular}

Table 2. Beta characters in different length of time.

\begin{tabular}{cccccc}
\hline Group & Length of time & Max & Min & Average & Standard deviation \\
\hline 1 & 6 months & 1.9728 & 0.1866 & 1.1305 & 0.0794 \\
2 & 12 months & 2.1555 & 0.5288 & 1.1916 & 0.0649 \\
3 & 18 months & 2.3744 & 0.6496 & 1.2257 & 0.0627 \\
4 & 24 months & 2.0877 & 0.6181 & 1.1930 & 0.0546 \\
5 & 36 months & 2.0069 & 0.5443 & 1.1634 & 0.0508 \\
6 & 48 months & 1.9497 & 0.5461 & 1.1762 & 0.0464 \\
7 & 60 months & 1.9127 & 0.5460 & 1.1716 & 0.0435 \\
8 & 72 months & 1.8801 & 0.5059 & 1.1647 & 0.0416 \\
\hline
\end{tabular}


Table 3. T statistic test result.

\begin{tabular}{|c|c|c|c|c|c|c|c|c|}
\hline Group & 1 & 2 & 3 & 4 & 5 & 6 & 7 & 8 \\
\hline 1 & - & $2.321^{\star *}$ & $3.643^{\star *}$ & $2.463^{\star *}$ & 1.314 & $1.858^{\star}$ & $1.693^{\star}$ & 1.417 \\
\hline 2 & $2.321^{* *}$ & - & 1.377 & 0.059 & 1.197 & 0.666 & 0.875 & 1.190 \\
\hline 3 & $3.643^{* *}$ & 1.377 & - & 1.377 & $2.669^{* *}$ & $2.162^{* *}$ & $2.393^{* *}$ & $2.725^{\star *}$ \\
\hline 4 & $2.463^{\star *}$ & 0.059 & 1.377 & - & 1.317 & 0.763 & 0.984 & 1.317 \\
\hline 5 & 1.314 & 1.197 & $2.669^{* *}$ & 1.317 & - & 0.593 & 0.388 & -0.062 \\
\hline 6 & $1.858^{*}$ & 0.666 & $2.162^{\star \star}$ & 0.763 & 0.593 & - & 0.219 & 0.560 \\
\hline 7 & $1.693^{*}$ & 0.875 & $2.393^{* *}$ & 0.984 & 0.388 & 0.219 & - & 0.344 \\
\hline 8 & 1.417 & 1.190 & $2.725^{\star \star}$ & 1.317 & -0.062 & 0.560 & 0.344 & - \\
\hline
\end{tabular}

Note: ${ }^{*}$ indicates the coefficient is significant at $5 \%$ level. ${ }^{*}$ indicates the coefficient is significant at $10 \%$ level.

average beta mainly range from 1.1 to 1.2 and the standard deviations are less than 0.1 which indicates that the beta difference is small. As the market beta is 1.0 which means the systematic risk of the listed companies are highly similar with the systematic risk of the market. With the assumption of the stocks' price are equal to their value and there is no excess return for unsystematic risk, there is little difference of return in investing in single stock and market index.

2) Mean difference of beta coefficients

As showed in Table 3, T statistic test result which used to examine the mean difference of beta that estimated by different length of time has been showed in exhibit 3. Group 1 to 8 is the same as Table 3 , group 1 means the length of time is 6 months and group 8 means the length of time is 72 months.

When the significant level is $5 \%$, the number of significant in the group is 7 , the probability is $25.00 \%$, that is, the probability of the mean betas are different in different estimated length of time is $25.00 \%$. When the significant level is $10 \%$, the number of significant is 10 , the probability is $32.14 \%$, that is, the probability of the mean betas are different in different estimated length of time is $32.14 \%$. It can be said that the length of time for betas estimating cause a considerable difference and the selection of different estimation times is very important for beta estimating.

\subsection{Stability of Beta Coefficients}

1) Regression results in different length of time for estimating

As showed in Table 4, the numbers of dummy variable that are significant in the significant level are $5 \%$ and $10 \%$. As the time phase for the regression is from January 2008 to December 2013, the based time phase is from January 2008 to June 2008, the corresponding time phase for b1 is from July 2008 to December 2008, b2 is from January 2009 to June 2009, and so on, b11 is from July 2013 to December 2013.

When the significant level is $5 \%$, the numbers of significant dummy variable are 348 which mean there 348 betas are unstable. When the significant level is 
Table 4. Regression results for 6 months.

\begin{tabular}{ccccccc}
\hline & \multicolumn{3}{c}{ Significant level 5\% } & \multicolumn{3}{c}{ Significant level 10\% } \\
\cline { 2 - 7 } $\begin{array}{c}\text { Dummy } \\
\text { variables }\end{array}$ & $\begin{array}{c}\text { No. of } \\
\text { significant }\end{array}$ & $\begin{array}{c}\text { No. of } \\
\text { significant } \\
\text { and positive }\end{array}$ & $\begin{array}{c}\text { No. of } \\
\text { significant } \\
\text { and negative }\end{array}$ & $\begin{array}{c}\text { No. of } \\
\text { significant }\end{array}$ & $\begin{array}{c}\text { No. of } \\
\text { significant } \\
\text { and positive }\end{array}$ & $\begin{array}{c}\text { No. of } \\
\text { significant } \\
\text { and negative }\end{array}$ \\
\hline b1 & 46 & 32 & 14 & 65 & 45 & 20 \\
b2 & 42 & 39 & 3 & 59 & 49 & 10 \\
b3 & 39 & 10 & 29 & 54 & 14 & 40 \\
b4 & 23 & 13 & 10 & 43 & 20 & 23 \\
b5 & 54 & 9 & 45 & 69 & 11 & 58 \\
b6 & 9 & 5 & 4 & 22 & 11 & 11 \\
b7 & 24 & 17 & 7 & 41 & 29 & 12 \\
b8 & 28 & 12 & 16 & 36 & 18 & 18 \\
b9 & 27 & 10 & 17 & 45 & 20 & 25 \\
b10 & 27 & 13 & 14 & 36 & 14 & 22 \\
b11 & 29 & 14 & 15 & 44 & 19 & 25 \\
Total & 348 & 174 & 174 & 514 & 250 & 264 \\
\hline
\end{tabular}

$10 \%$, the numbers of significant dummy variable are 514 which mean there are 514 unstable betas. Otherwise, the dummy variables which are significant and positive are more than that are significant and negative in b1, b2 and b7 which mean the betas are supposed to increase, the corresponding time phases in this three coefficients are July 2008 to December 2008, January 2009 to June 2009, July 2011 to December 2011 when the market in China were mostly bull markets. Otherwise, the numbers of dummy variables which are significant and negative are less than that are significant and positive for the other coefficients when the market were mostly a bear market. Thus, beta is tend to increase in the bull market and decrease in the bear market.

When the length of time for estimation is 12 months, the based time phase is January 2008 to December 2008, the corresponding time phase for b1 is January 2009 to December 2009, and so on, b5 is from January 2013 to December 2013.

As shown in Table 5, the significant numbers of dummy variable are 179 when significant level is $5 \%$ and 257 when it is $10 \%$. Similar to above, the betas were supposed to increase when the market was in a bull market and decrease when the market was in a bear market.

As shown in Table 6, when the length was 18 months, January 2008 to June 2009 was the base period and b1 is from July 2009 to December 2010, and so on. As shown in Table 6, the significant numbers are 158 for significant level is $5 \%$ and 210 for significant level is $10 \%$.

As shown in Table 7, when the length was 24 months, January 2008 to December 2009 was the based period. The significant numbers are 96 when significant level is $5 \%$ and 119 when it is $10 \%$.

As shown in Table 8, when the length was 36 months, January 2008 to De- 
cember 2010 was the based period. The significant numbers are 47 when significant level is $5 \%$ and 63 when it is $10 \%$.

2) Length of time for estimating and beta stability

As shown in Table 9, when the significant level is $10 \%$, the proportion of unstable beta is $22.47 \%$ for 6 months and is $30.29 \%$ for 36 months. When the sig-

Table 5. Regression results for 12 months.

\begin{tabular}{ccccccc}
\hline & \multicolumn{3}{c}{ Significant level 5\% } & \multicolumn{3}{c}{ Significant level 10\% } \\
\cline { 2 - 7 } $\begin{array}{c}\text { Dummy } \\
\text { variables }\end{array}$ & $\begin{array}{c}\text { No. of } \\
\text { significant }\end{array}$ & $\begin{array}{c}\text { No. of } \\
\text { significant } \\
\text { and positive }\end{array}$ & $\begin{array}{c}\text { No. of } \\
\text { significant } \\
\text { and negative }\end{array}$ & $\begin{array}{c}\text { No. of } \\
\text { significant }\end{array}$ & $\begin{array}{c}\text { No. of } \\
\text { significant } \\
\text { and positive }\end{array}$ & $\begin{array}{c}\text { No. of } \\
\text { significant } \\
\text { and negative }\end{array}$ \\
\hline b1 & 31 & 18 & 13 & 40 & 24 & 16 \\
b2 & 50 & 4 & 46 & 67 & 7 & 60 \\
b3 & 26 & 16 & 10 & 48 & 27 & 21 \\
b4 & 38 & 16 & 22 & 50 & 20 & 30 \\
b5 & 34 & 11 & 23 & 52 & 14 & 38 \\
Total & 179 & 65 & 114 & 257 & 92 & 165 \\
\hline
\end{tabular}

Table 6. Regression results for 18 months.

\begin{tabular}{ccccccc}
\hline & \multicolumn{3}{c}{ Significant level 5\% } & \multicolumn{3}{c}{ Significant level 10\% } \\
\cline { 2 - 6 } $\begin{array}{c}\text { Dummy } \\
\text { variables }\end{array}$ & $\begin{array}{c}\text { No. of } \\
\text { significant }\end{array}$ & $\begin{array}{c}\text { No. of } \\
\text { significant } \\
\text { and positive }\end{array}$ & $\begin{array}{c}\text { No. of } \\
\text { significant } \\
\text { and negative }\end{array}$ & $\begin{array}{c}\text { No. of } \\
\text { significant }\end{array}$ & $\begin{array}{c}\text { No. of } \\
\text { significant } \\
\text { and positive }\end{array}$ & $\begin{array}{c}\text { No. of } \\
\text { significant } \\
\text { and negative }\end{array}$ \\
\hline b1 & 68 & 5 & 63 & 79 & 6 & 73 \\
b2 & 42 & 19 & 23 & 60 & 30 & 30 \\
b3 & 48 & 13 & 35 & 71 & 20 & 51 \\
Total & 158 & 37 & 121 & 210 & 56 & 154 \\
\hline
\end{tabular}

Table 7. Regression results for 24 months.

\begin{tabular}{ccccccc}
\hline & \multicolumn{3}{c}{ Significant level 5\% } & \multicolumn{3}{c}{ Significant level 10\% } \\
\cline { 2 - 6 } $\begin{array}{c}\text { Dummy } \\
\text { variables }\end{array}$ & $\begin{array}{c}\text { No. of } \\
\text { significant }\end{array}$ & $\begin{array}{c}\text { No. of } \\
\text { significant } \\
\text { and positive }\end{array}$ & $\begin{array}{c}\text { No. of } \\
\text { significant } \\
\text { and negative }\end{array}$ & $\begin{array}{c}\text { No. of } \\
\text { significant }\end{array}$ & $\begin{array}{c}\text { No. of } \\
\text { significant } \\
\text { and positive }\end{array}$ & $\begin{array}{c}\text { No. of } \\
\text { significant } \\
\text { and negative }\end{array}$ \\
\hline b1 & 46 & 11 & 35 & 58 & 13 & 41 \\
b2 & 50 & 18 & 32 & 61 & 21 & 40 \\
Total & 96 & 29 & 67 & 119 & 34 & 81 \\
\hline
\end{tabular}

Table 8. Regression results for 36 months.

\begin{tabular}{ccccccc}
\hline & \multicolumn{3}{c}{ Significant level 5\% } & \multicolumn{3}{c}{ Significant level 10\% } \\
\cline { 2 - 7 } $\begin{array}{c}\text { Dummy } \\
\text { variables }\end{array}$ & $\begin{array}{c}\text { No. of } \\
\text { significant }\end{array}$ & $\begin{array}{c}\text { No. of } \\
\text { significant } \\
\text { and positive }\end{array}$ & $\begin{array}{c}\text { No. of } \\
\text { significant } \\
\text { and negative }\end{array}$ & $\begin{array}{c}\text { No. of } \\
\text { significant }\end{array}$ & $\begin{array}{c}\text { No. of } \\
\text { significant } \\
\text { and positive }\end{array}$ & $\begin{array}{c}\text { No. of } \\
\text { significant } \\
\text { and negative }\end{array}$ \\
\hline b1 & 47 & 25 & 22 & 63 & 31 & 32
\end{tabular}


Table 9. Beta stability and length of time.

\begin{tabular}{ccc}
\hline \multirow{2}{*}{ Length of time } & \multicolumn{2}{c}{ Proportion of beta unstable } \\
\cline { 2 - 3 } & $15.21 \%$ & Significant level 10\% \\
\hline 6 months & $17.21 \%$ & $22.47 \%$ \\
12 months & $25.32 \%$ & $24.71 \%$ \\
18 months & $23.08 \%$ & $33.65 \%$ \\
24 months & $22.60 \%$ & $28.61 \%$ \\
36 months & $30.29 \%$ \\
\hline
\end{tabular}

Note: the proportion calculated by the number of significant dummy variables divided by the total dummy variables. For the length of time is 6 months and significant level is $10 \%$, the proportion $22.47 \%$ is calculate by $514 /(208 \times 11), 514$ are the numbers of the significant dummy variables, 208 are the sample numbers, 11 are the dummy variables for each sample's regression. For the length of time is 36 months and significant level is $10 \%$, the proportion $30.29 \%$ is calculate by $63 /(208 \times 1)$,

nificant level is $5 \%$, the proportion of unstable beta is $15.21 \%$ for 6 months and is $22.60 \%$ for 36 months. Mostly, the proportion was increasing with the length of time increased which means the beta is likely to become less stable as the estimation duration increases in china's stock market. This conclusion is completely adverse with the investigations that made in the developed market which the beta tends to be more stable with the increased of the estimation duration.

Since the stability of the beta decreases with the increase of the estimated duration, the most stable for beta estimation is 6 month. In spite of that, the proportion of 12 months is slightly higher than that in 6 months. As weekly data has been used in the regression, there are nearly 32 data if 6 months are selected and there are nearly 52 data can be used if 12 months are selected. In thinks about this, the optimal estimation time is 12 months.

\subsection{Beta Stability in Different Markets}

In china, the public stock market has been divided into four part which are main-board Market of Shanghai (SH), Main-board Market of Shenzhen (SZ), Small and Medium Enterprise Board that for the small and median size companies, Growth Enterprise Market that for the companies have a high growth rate. This paper only make researches on the first three markets as the Growth Enterprise Market was set up after 2009.

As showed in Table 10, the proportion of unstable beta in the Main-board market in $24.04 \%$ while it is $30.00 \%$ for the Small and Medium Enterprise Board when the significant level is $10 \%$ indicates that the companies in Small and Medium Enterprise Board tend to have higher unstable betas. At the same time, the proportion of unstable beta in the Main-board Market of SZ is slightly higher than that in the Main-board Market of SH. To sum up, the Small and Medium Enterprise Board's companies' betas are higher unstable than that in Main-board market. In Main board market, the beta stability is worse in the market of SZ. For beta risk, Small and Medium Enterprise Board is higher than Main Board market, Main Board market of SZ is higher than Main Board market of SH. 
Table 10. Beta stability in different markets.

\begin{tabular}{ccc}
\hline \multirow{2}{*}{ Markets } & \multicolumn{2}{c}{ Proportion of beta unstable (length of time: 12 months) } \\
\cline { 2 - 3 } & Significant level 5\% & Significant level 10\% \\
\hline Main board market of SZ & $16.63 \%$ & $25.12 \%$ \\
Main board market of SH & $16.53 \%$ & $23.32 \%$ \\
Main board market & $16.57 \%$ & $24.04 \%$ \\
Small and medium enterprise & $20.00 \%$ & $30.00 \%$ \\
board & $17.21 \%$ & $24.71 \%$ \\
Total & & \\
\hline
\end{tabular}

Table 11. Beta stability in different industries.

\begin{tabular}{ccc}
\hline \multirow{2}{*}{ Industries } & \multicolumn{2}{c}{ Proportion of beta unstable (length of time: 12 months) } \\
\cline { 2 - 3 } & Significant level 5\% & Significant level 10\% \\
\hline Manufacturing & $18.57 \%$ & $27.14 \%$ \\
Real estate & $24.40 \%$ & $35.60 \%$ \\
Wholesale and retail & $23.33 \%$ & $32.00 \%$ \\
Utilities & $12.80 \%$ & $16.00 \%$ \\
Transportation & $9.47 \%$ & $15.79 \%$ \\
total & $17.21 \%$ & $24.71 \%$ \\
\hline
\end{tabular}

\subsection{Beta Stability in Different Industries}

As shown in Table 11, the industry difference in beta stability showed that manufacturing, real estate and wholesale and retail have the highest unstable beta while utilities and transportation have the lowest unstable beta. Manufacturing, real estate and wholesale and retail are all cyclical industries. The proportion of beta unstable in real estate industry is $35.60 \%$ when the significant level is $10 \%$ and it is the highest among all. The high growth rate of housing market and the high leverage in china's real estate companies could be the reason about the high unstable of their beta coefficients. At the same time both manufacture and wholesale and retail have experienced a high growth rate during the past ten years which could be the main reason.

Utilities and transportation are both noncyclical industries mostly have the characteristics of low growth rate, stable income and cash flow, low correlation with the economic growth and those can be the main reasons that course they have the lowest stable of beta.

\subsection{Beta Stability and Market Value}

This part aimed to make researches about whether bigger companies have more stable beta coefficients. As the bigger companies mostly have various businesses and higher diversified, their business may more resistant to risk and their beta coefficients may more stable. In this part, the samples were divided into 5 groups according their market value which group 1 represents the smallest companies and group 5 represents the biggest companies. As showed in Table 12. 
Table 12. Beta stability and market value.

\begin{tabular}{cccccc}
\hline \multirow{2}{*}{ Group } & \multicolumn{4}{c}{ Proportion of beta unstable (Significant level 10\%) } \\
\cline { 2 - 6 } & 6 months & 12 months & 18 months & 24 months & 36 months \\
\hline 1 & $24.68 \%$ & $26.67 \%$ & $33.33 \%$ & $29.76 \%$ & $26.19 \%$ \\
2 & $19.48 \%$ & $24.29 \%$ & $30.95 \%$ & $35.71 \%$ & $28.57 \%$ \\
3 & $21.00 \%$ & $27.14 \%$ & $35.71 \%$ & $35.71 \%$ & $28.57 \%$ \\
4 & $23.59 \%$ & $30.95 \%$ & $40.48 \%$ & $35.71 \%$ & $30.95 \%$ \\
5 & $31.36 \%$ & $23.50 \%$ & $34.17 \%$ & $23.75 \%$ & $32.50 \%$ \\
\hline
\end{tabular}

When the length of time for estimation is 6 months, proportion of beta unstable group 1 and group 2 are $24.68 \%$ and 19.48 , it is $23.59 \%$ and $31.36 \%$ for group 4 and group 5 which are much higher than group 1 and 2. It is similar when the length of time for estimation is 12 months, 18 months, 24 months and 36 months which means that smaller companies mostly have more stable betas and it is completely opposite with the assumption above.

\section{Conclusions}

This paper examined the stability of beta in China's stock market across estimation duration, markets, industries and market size. The $t$ statistic result shows that the estimation duration is really important for beta estimating, different length of time for regression can create a great difference in beta. Completely adverse with the conclusion in the developed market, the beta stability is likely to be more unstable with the increases of the estimation duration and beta tends to increases in the bull market and decreases in the bear market. In china, beta risk is much higher in the Small and Medium Enterprise Board than in the Main-board market, and it is higher in the Main-board market in SZ than in the Main-board market in SH. For industries, beta is less stable in cyclical industries and high growth industries. Also beta is supposed to be more stable for small companies than big companies.

However, more research still should be done further according to the article. For example, one of the conclusion that the beta tends to increase during the bull market and decrease during the bear market. Further investigation can be made to test if there is any arbitrage opportunity for this conclusion? Otherwise, the article hasn't researched deeply on the reasons about the longer the estimation duration is, the more unstable the beta in China's stock market which completely adverse with the conclusion in the developed market.

\section{References}

[1] Sharpe, W.F. (1963) A Simplified Model for Portfolio Analysis. Management Science, 9, 277-293. https://doi.org/10.1287/mnsc.9.2.277

[2] Fabozzi, F.J. and Francis, J.C. (1978) Bate As a Random Coefficient. Journal Financial and Quantitative Analysis, 13, 101-116. https://doi.org/10.2307/2330525

[3] Blume, E. (1971) On the Assessment of Risk. Journal of Finance, 24, 275-288. 
https://doi.org/10.1111/j.1540-6261.1971.tb00584.x

[4] Roenfeidt, R.L., Griepentrog, G.L. and Pflaum, C.C. (1978) Further Evidence on the Stationary of Beta Cofficients. Journal Financial and Quantitative Analysis, 3, 117121. https://doi.org/10.2307/2330526

[5] Brooks, R.D., Faff, R.W. and Ariff, M. (1998) An Investigation into the Extent of Beta in Stability in the Singapore Stock Market. Pacific-Basin Finance Journal, 6, 87-101. https://doi.org/10.1016/S0927-538X(97)00025-5

[6] Levitz, R.A. (1974) Market Risk and the Management of Institutional Equity Portfolio. Financial Analyst Journal, 30, 53-60. https://doi.org/10.2469/faj.v30.n1.53

[7] Lam, K.S.K. (1999) Some Evidence on the Distribution of Beta in Hong Kong. Applied Financial Economics, 9, 251-262. https://doi.org/10.1080/096031099332320

[8] Deb, S.G. and Misra, S. (2011) Are Equity Stable? Evidence from Indian Equity Market. The IUP Journal of Applied Finance, 17, 5-25.

Submit or recommend next manuscript to SCIRP and we will provide best service for you:

Accepting pre-submission inquiries through Email, Facebook, LinkedIn, Twitter, etc. A wide selection of journals (inclusive of 9 subjects, more than 200 journals)

Providing 24-hour high-quality service

User-friendly online submission system

Fair and swift peer-review system

Efficient typesetting and proofreading procedure

Display of the result of downloads and visits, as well as the number of cited articles

Maximum dissemination of your research work

Submit your manuscript at: http://papersubmission.scirp.org/

Or contact jssm@scirp.org 